\title{
Nanocellulose Coating Associated with Lemongrass Essential Oil at Postharvest of Blackberry Fruits
}

\author{
Evaldo Leandro Potma da Silva ${ }^{\mathrm{a}}$; Tereza Cristina de Carvalho ${ }^{\mathrm{b}}$; Ricardo Antonio \\ Ayub $^{\mathrm{c} *}$; Mariana Celano Menezes de Almeida ${ }^{\mathrm{a}}$
}

A undergraduate student, Laboratory of Biotechnology Applied to Fruit, Ponta Grossa State University, Paraná, Brazil.

${ }^{\mathrm{b}}$ Agr. Eng, Prof. of agronomy, post doctoral student, Ponta Grossa State University, Paraná, Brazil.

${ }^{c}$ Agr. Eng., Full Prof., Biotechnology Lab. Applied to Fruitculture, Ponta Grossa State University, Paraná, Brazil.

*Correspondent author: Department of Crop Science, Ponta Grossa State University,

Uvaranas Campus, General Carlos Cavalcanti Avenue, 4748 - 84030-900, Ponta

Grossa, Paraná, Brazil. Telephone: 55-42-32203088, E-mail address: rayub@uepg.br

\begin{abstract}
Blackberry is a fruit that has high nutritional value, a factor that has expanded its consumption worldwide. However, due to the fragility of the fruits and the high incidence of postharvest diseases, the fruits have a short shelf life. Thus, the objective of this study was to evaluate whether the application of coatings based on microfibrillated cellulose (NC) and lemongrass essential oil (EO) nanoparticles can prolong the shelf life of blackberry fruits after harvest. EO-coated blackberry fruits at nanocellulose concentrations were analyzed as follows: $0 ; 0.2 ; 0.4 ; 0.6$ and $0.8 \%$, in addition to the control treatment of which neither essential oil nor nanocellulose was used, for each treatment five repetitions were used. The fruits were analyzed soon after the application of the cover and at three and six days after storage. Fruit quality was assessed by soluble solids (SS), titratable acidity (TA), pH, fresh weight loss (FWL) and colorimetric parameters such as luminosity, hue angle and fruit peel chroma. Coating on EO (1000 ppm) blackberries combined with $\mathrm{NC}$ at concentrations of $0.2,0.4$ and $0.6 \%$ is promising in preserving blackberry fruits and reducing the process color reversal, up to six days of
\end{abstract}


storage. The $0.4 \% \mathrm{NC}+1000 \mathrm{ppm}$ EO conjugated coating showed no SS changes in blackberry fruits during the six days of storage.

Keywords: Morus sp.; cellulose; cymbopogon citratus; Post harvest quality

\section{Introduction}

Blackberry is part of the small fruits group, known for the high amount of antioxidants substances on its composition. It is very explored for the nutraceutical industry for protecting human body cells of the harms caused by free radicals, which are responsible for chronic diseases (Barbieri and Vizzotto, 2012; Curi et al., 2014; Hirsch et al., 2012; Kafkas et al., 2006; Jacques and Zambiazi, 2011).

Although blackberry has bioactives that directly attracts the consumer, the fruit has a fragile structure, which reduces its consumption in natura (Cia et al., 2007; Oliveira et al., 2013). Its lifespan is relatively short after harvesting, because of the high content of water, its metabolism and the occurrence of diseases demanding care with storage (Bischoff et al., 2013; Palharini et al., 2015).

The use of edible coating is one of the effective technological alternatives in extending the lifespan of fruits and vegetables. This is justified, because the material layer acts with excellent property as an artificial barrier, maintaining its postharvest quality, reducing production costs (Rhim et al., 2013; Sena et al., 2016; Gol et al., 2015).

Between the new perspectives of the use of coatings, cellulose can be highlighted. It is a natural polymer that, when reduced to nanocellulose, presents a crystalline structure with wide industrial applications (Kim et al., 2015). Its nanoscale dimension and its capacity of forming a strong nanoporous tangled network, encourage the emergence of new high value applications for the food industry (Lavoine et al., 2012).

This particle has been widely studied as a component of materials, including food packaging (Azeredo et al., 2017; Nsor-Atindana et al., 2017). A benefit of the NC is its good water retention capacity, a feature that can be explored when applying coatings on fruits that have a high transpiratory rate (Ditzel et al., 2017). Such fact contributes to increase the shelf life of fready-to-eat foods (Cazón et al., 2017), especially due to the properties of the nanofibrillated cellulose, which has high strength and rigidity, low 
weight and biodegradability. The efficiency of this coat in the conservation of papaya fruits was verified by Trigo et al. (2012).

At the same time, natural products extracted from medicinal plants are been studied as an alternative for the control of diseases and/or reduction of degrading processes in fruits, mainly in postharvest conditions (Carnelossi et al., 2009). Between these products, the OE shows themselves as a promising option (Lorenzetti et al., 2011).

In this context, food industry is developing new packaging systems by incorporating EO or its main compounds into films (Balloch et al., 2018).

Lemongrass EO is an efficient and sustainable option in postharvest treatment, as it interrupts the development of microorganisms (Santos Neto et al., 2016; BermudezVasquez et al., 2019). Associated with other edible coatings, it is explored on guava postharvest (Rozwalka et al., 2008; Murmu and Mishra 2018).

Considering the blackberry short postharvest life and the importance this culture represents for the market, the objective of this work was to evaluate if the application of the coatings based on nanoparticles of nanofibrillated cellulose (NC) and lemon grass essential oil (EO) is able of extend the shelf life of blackberry fruits after harvest.

\section{Material and methods}

Blackberry fruits of the cultivar Brazos were obtained from a commercial orchard in Ponta Grossa city, Paraná. The harvest was done during the morning and the fruits were immediately conduced to the laboratory, where they were washed in running water, dried with the aid of paper towels and divided into six portions of 200 grams, which were used to make up the treatments.

To obtain the NC, pinewood residues submitted to acid hydrolysis with sulfuric acid in a cold water bath to remove lignin were used. Passing through a filtration process, and, finally, dissolving in water to obtain the biofilm according to the methodology described by Ditzel et al. (2017).

To obtain nanocellulose concentrations, the standart solution of $2 \%$ in aqueous medium was diluted, obtaining $0.2 \%, 0.4 \%, 0.6 \%$ and $0.8 \%$. After preparing the NC solutions, lemon grass EO was added on each solution, at $1000 \mathrm{ppm}$ concentration, for all the treatments with NC, as the methodology of Rozwalka et al. (2008). 
The biofilm application was done by dipping the fruits in the solution with a waiting time of one minute and subsequent drying for complete adhesion to the fruit; the procedure being conducted at laboratory room temperature. After the treatment applications, the fruits were evaluated according to the quality criteria. Afterwards, the fruits were packed on closed plastic boxes, which allowed ventilation. The set was kept over a bench, in the laboratory, without sunlight exposition. After the fruit coating, the analyses were repeated after a storage period of three and six days.

On this way, a total of three evaluation periods were established, to know: right after harvest ( 0 days), at three and six days after fruit coverage. For each evaluation periods, six NC + EO combinations were analyzed: control (without $\mathrm{NC}$ and $\mathrm{EO}$ ), $0 \%$ $(\mathrm{NC})+1000 \mathrm{ppm}(\mathrm{EO}), 0.2 \%(\mathrm{NC})+1000 \mathrm{ppm}(\mathrm{EO}), 0.4 \%(\mathrm{NC})+1000 \mathrm{ppm}(\mathrm{EO}), 0.6 \%$ $(\mathrm{NC})+1000 \mathrm{ppm}(\mathrm{EO})$ and $0.8 \%(\mathrm{NC})=1000 \mathrm{ppm}()$. Still related to the treatments, on the sixth evaluation day for the treatment control, the fruits were discarded, because they were deteriorated and without possibility of been evaluated.

2.1. The fruits were analyzed for the PMF, colorimetry, SS, AT and $\mathrm{pH}$.

To obtain the FWL (\%), an analytical bench scale of the Shimadzu brand, model ATX224 was used, where the fruit was identified since the first day and was weighted every three days to evaluate the fresh weight loss. The final values were calculated as a percentage based on the initial fresh fruit weight.

To the quality analysis, SS ( ${ }^{\circ}$ Brix), AT (\% malic acid) and $\mathrm{pH}$ were evaluated. The SS were quantified using a Biosystems LTDA bench refractometer (model 103). The AT was quantified by titration with $0,1 \mathrm{~N} \mathrm{NaOH}$ and further calculated by the formula $[\mathrm{ATT}=(\mathrm{n} . \mathrm{N} . \mathrm{Eq}) / \mathrm{V}]$, where $\mathrm{n}$ is the volume of sodium hydroxide solution spent on titration in $\mathrm{mL}, \mathrm{N}$ is the normality of the sodium hydroxide solution, $\mathrm{V}$ is the sample volume in $\mathrm{mL}$ and $\mathrm{Eq}$ is the equivalent gram of malic acid.

The $\mathrm{pH}$ values were estimated with a tec 5 model TECNAL bench pHgameter.

To the fruit coloration, a Konica Minolta bench colorimeter was used. The L (lightening) parameters reading, $\mathrm{a}^{*}$ and $\mathrm{b}^{*}$ allowed to calculate the Hue angle and the Chroma or color saturation. The Hue angle is equivalent to the [tangent $\left.\operatorname{arc}\left(\mathrm{b}^{*} / \mathrm{a}^{*}\right)\right]$ and Chroma to $\left[\left(a^{* 2}+b^{* 2}\right)^{1 / 2}\right]$ according to MINOLTA, 1994.

\subsection{Statistical analysis}


The data were analyzed using a completely randomized design (CRD). In the statistical procedure, the subdivided plots were adopted, with $(3 \times 6)$ scheme, being the first factor evaluation days (immediately after harvest, at three and six days of storage) and the second, fruit coating $(0 ; 0.2 ; 0.4 ; 0.6$ and $0.8 \% \mathrm{NC}+\mathrm{OE}$, and the absolute control without NC and OE), with five repetitions. The averages were compared by the Student Newman Keuls test at $\mathrm{p} \leq 0.05$. When there was an interaction of the $\mathrm{NC}+\mathrm{OE}$ concentrations in each evaluation period, the regression analysis was performed. All the data were computed and entered in Excel, looking for generate the tables and graphics. The statistical analysis was done using the program RStudio (2018).

\section{Results}

The $\mathrm{pH}, \mathrm{AT}, \mathrm{SS}$ and PMF results for blackberry fruits are shown in Table 1 . The comparison of the results obtained between the different evaluation periods, right after coating application, at three and six days of storage (Table 1).

It is observed that $\mathrm{pH}$ values in blackberry fruits varies according to the used coating (Table 1). To the treatments with $\mathrm{OE}$ and $\mathrm{NC}$ at $0.2 \%$ and $0.8 \%$ concentrations at three and six days after storage, the highest $\mathrm{pH}$ values occurred. Already at six days of evaluation, coating with $\mathrm{OE}$ and $\mathrm{NC}$ at $0 ; 0.4$ and $0.6 \%$ at the sixth day, had the higher $\mathrm{pH}$ values (Table 1). High $\mathrm{pH}$ values are indicatives of fruit deterioration (Bischoff et al., 2013). In this sense, lower $\mathrm{pH}$ values indicate fruits that are in less deterioration process. Thus, the best values were found for $\mathrm{OE}+\mathrm{NC}$ coating at the following values: $0.2 \%$ (immediately after coating application), $0.4 \%$ at three days of coating and 0.6 and $0.8 \%$ $\mathrm{NC}$ right after coating.

The Figure 1 shows the blackberry behavior as different concentrations of NC were applied. It is worth noting that the periods of evaluation tendency lines $(0,3$ and 6 days) that showed significant differences are represented in isolation.

The AT (Figure 1B) and SS (Figure 1C), of blackberry fruits evaluated at six days after storage, presented values reduction tendency as there was an increase in NC concentration. High titratable acidity concentrations may indicate better fruit quality, because it confers flavor to the fruits. 
The MPF (Figure 1D) of blackberry fruits becomes higher as the NC concentration increased to $0.8 \%$. However, it is noteworthy that when evaluating the individual effect of each NC concentration (Table 1), PMF tends to reduce until the sixth day of storage.

The results of luminosity, Hue angle and Chroma for blackberry fruits are presented in Table 2. The comparison of the obtained results between the different evaluation periods, right after coating application, at three and six days of storage (Table 2 ), records an oscillation of values between the analyzed treatments.

The Hue angle (Table 2) showed no significative differences for EO+NC concentrations at $0,0.2,0.6$ and $0.8 \%$ regardless of the evaluation period. For the control treatments and $\mathrm{OE}+\mathrm{NC}$ at $0.4 \%$ concentration, on the third day of evaluation the fruits already had the highest Hue angle values (Table 2).

When analyzing the average values of Chroma (Table 2), it is observed that the blackberry fruits coating with $\mathrm{OE}+\mathrm{NC}$ at concentrations of $0.2 ; 0.4$ and $0.6 \%$, determined at six days of storage presented the highest values (Table 2). These results are indicative of better fruit quality ( $\mathrm{OE}+\mathrm{NC} 0.2,0.4$ and $0.6 \%$,), as it is an indicative of the fruit color intensity, that is, higher values indicate more intense samples which pleases consumers (Hirsch et al., 2012).

Figure 2 shows the behavior of blackberry fruits as different concentrations of NC are used, as for luminosity (A), Hue angle (B) and Chroma (C). It is noteworthy that the tendency lines of the evaluation periods ( 0,3 and 6 days) that presented significative differences are been displayed in isolation.

It is observed that the blackberry fruits luminosity (Figure 2A), for fruits evaluated at six days after storage, the peak value was $0.4 \% \mathrm{EO}+\mathrm{NC}$. The fruit color changes its luminosity and is an important parameter for producers and consumers as it indicates if the fruit has or not ideal conditions for its commercialization and consumption (Hirsch et al., 2012), as preferably strong and bright color.

The average Hue angle data (Figure 2B) for blackberry fruits evaluated at six days of storage show an increasing value trend as the concentration of NC increased. Thus, at six days of storage, the increase in the $\mathrm{NC}+\mathrm{EO}$ concentrations used for coverage keeps the blackberry fruits in their original coloration, not allowing the fruits to change their coloration to a reddish skin coloration.

As for the average values of Chroma, there is a tendency of value reduction, as the NC concentrations increase, both for fruits evaluated right after harvest and for those evaluated at six days after storage (Figure 2C). However, it is noteworthy that the 
individual evaluation of each $\mathrm{NC}$ concentration (Table 3), especially for the $\mathrm{OE}+\mathrm{NC}$ coatings at concentrations $0.2,0.4$ and $0.6 \%$, gave at six days of evaluation, the highest Chroma values.

\section{Discussion}

The process of fruit deterioration occurs due to the greater respiratory activity of the fruit. As cells breathe intensely, there is a higher consumption of sugars and organic acids contained in it. (Antunes et al., 2003; Taiz and Zeiger, 2013); This fact reduces the fruit lifespan. The fruit coating with biofilms can limit the oxygen diffusion, reducing the respiratory rate and, consequently, the deterioration.

The TA of blackberry fruits (Table 1) coated with NC and lemongrass EO at 0.2; 0.2 and $0.6 \%$ concentrations presented the greatest acidity values, been this result obtained right after the coating of the fruits. It is worth noting that high values of titratable acidity are indicatives of the presence of organic acids, which confer flavor to the fruit. According to Hirsch et al. (2012), acidity is one of the important parameters used in classification of pulps for juice production. The $\mathrm{pH}$ and TA values coincide with those found by Turmanidze et al. (2016) where the application of edible coatings did not show significant changes during the fruit storage period. The average valued of TA coincide with the ones found by Curi et al. (2014) to the cultivar Brazos, these values are within what is accepted for the fruits commercialization.

To the SS of blackberry fruits (Table 1), the highest ${ }^{\circ}$ Brix values were found to the $\mathrm{OE}+\mathrm{NC}$ coatings at concentrations of: $0.2 \%$ at the sixth day of evaluation; $0.6 \%$ and $0.8 \%$ at the third day of evaluation. The ${ }^{\circ}$ Brix is an indicative of the quantity of sugars in the fruits. The values obtained here (Table 1), ranged from 5.9 to $8.8^{\circ} \mathrm{Brix}$ and some of these agree with Curi et al. (2014), who obtained $7.4^{\circ}$ Brix for fruits of Brazos cultivar. However, these values can also be influenced by the management and climatic conditions of the plants in the field. According to Kafkas et al. (2006), the accumulation of reducing sugars (glucose and fructose) is very important to the blackberry postharvest physiology, been responsible for the fruits sweet flavor.

As storage progress (Table 1), it is observed that the fresh fruit loss becomes smaller, especially when the blackberry fruits coating is used. The smaller fresh fruit loss can be related to the low respiratory rate, because as the fruit tissues cells breathe, 
there is a sugar consumption contained on it (Antunes et al., 2003; Taiz and Zeiger, 2013). Other factors that interfere in the fresh weight loss reduction is the transpiration process, at storage temperature reduction (JOO et al., 2011; Soethe et al., 2016).

Alves and Bastos (2017), verified greater rigidity in strawberry fruits using biofilms. According to Assis (2009) and Yamamoto et al. (2011), calcium chloride, which may be present in the chemical composition of some biofilms, when associated with the pectin present in the cell wall of the cells lining the fruit, forms covalent bonds rising calcium pectate, component responsible for the external fruit layer rigidity. This component acts reducing the transpirations and, consequently, the fresh weight loss of the fruit.

To the blackberry fruits $\mathrm{pH}$ (Figure 1A), it was observed that the evaluation performed at three days after storage presented a $\mathrm{pH}$ reduction tendency as there were a NC concentration increase. Already to the fruits evaluated at six days, there is a $\mathrm{pH}$ stability with the NC concentrations increase (Figure 1A). The $\mathrm{pH}$ stability over the storage days and the SS increase do not coincide with the results found by Trigo et al. (2012), where $\mathrm{pH}$ increases decreased SS concentration in papaya fruits tested and consequently there was a reduction of the color attributes such as Chroma.

Observing the fruit luminosity results (Table 2), the application of EO+NC coating at $0.2,0.4$ and $0.6 \%$ presented high luminosity values at six days of storage. These results are indicative of better fruits quality, because the higher is the luminosity, the better is the visual quality of the blackberry fruits, as it keeps a shine that pleases the final consumer (Soethe et al., 2016).

Maintaining the postharvest life and quality of blackberries is a challenge for growers and packers due to several postharvest problems, including fresh weight loss and color reversal (Lawrence and Melgar, 2018). Looking for reducing these losses, the use of techniques as cooling and the use of packaging became viable alternatives (Bischoff et al., 2013). According to Bischoff et al. (2013), blackberry hue decreases during the storage days due to the fruit water content reduction. It is observed by the luminosity results (Table 2) that even at six days of storage, the blackberry coating with EO+NC at $0.2,0.4$ and $0.6 \%$ concentrations are promising in maintaining their quality.

According to Hirsch et al. (2012), the hue angle is a variable that is between $0^{\circ}$ and $90^{\circ}$, and the smaller the angle value, the redder the fruit. Such fact is not desirable for blackberry fruits, whose desirable color in the market is purple. Lower Hue values suggest that the fruits began to appear reddish over the days. This reddish appearance of 
the fruits pericarp (exocarp) is known as the blackberry color reversal process. The color reversal process is undesirable for producers as it impairs the fruits appearance and, consequently, reduces the value of the final product to consumers (Tosun et al., 2008).

Chroma values may be associated with the influence of the coating film color, which has a whitish coloration and are also linked to the increase of the fruits SS over the storage days due to the starch retrogradation into smaller sugar molecules (Trigo et al., 2012).

The lower luminosity values (Figure 2A), were found in the control treatments, $0 \%$ $\mathrm{NC}=\mathrm{EO}$, and with the highest concentrations of $\mathrm{NC}+\mathrm{EO}(0.6$ and $0.8 \%)$ and may result from alteration of some molecular structure of starch, which is responsible for increasing the fruit opacity (Brinch et al., 2013). The brightness decreases with the ripening of blackberry fruits, indicating that the color becomes more intense or darker. The appearance of the purple color may be related to the appearance of phenolic compounds (Tosun et al., 2008).

\section{Conclusions}

The application of coating associating lemongrass EO (1000ppm) and $\mathrm{NC}$ at 0.2 , 0.4 and $0.6 \%$ concentrations are promising in blackberry fruits conservation until six days of postharvest.

The blackberry fruit coating with $0.4 \% \mathrm{NC}+1000 \mathrm{ppm}$ of EO did not present SS changes during the six days of storage.

The visual appearance of the blackberry fruits, postharvest coated with $1000 \mathrm{ppm}$ of lemongrass EO associated with $0.2,0.4$ or $0.6 \%$ of $\mathrm{NC}$, maintains characteristics that retard the fruits color reversal process, up to six storage days.

\section{Note}

This research did not receive any specific grant from funding agencies in the public, commercial, or not-for-profit sectors. 


\section{References}

Assis, A.S.D., 2009. Produção e caracterização do biofilme de quitosana como envoltório protetor em morangos. [Doctoral thesis]. Federal University of Pernambuco, Recife, Brazil.

Alves, A.A., Bastos, R.A., 2017. Influência da aplicação de biofilmes com extrato vegetal de capim limão sobre a perda de peso e dureza de morangos. In.: VIII Simpósio de Pesquisa e Inovação 24 a 26 de outubro de 2017.

Antunes, L.E.C., Duarte Filho, J., Souza, C.M., 2003. Conservação pós-colheita de frutos de amoreira-preta. Pesquisa Agropecuária Brasileira, 38: 413-419.

Azeredo, H. M. C., Rosa, M. F., Mattoso, L. H. C., 2017. Nanocellulose in bio-based food packaging applications. Industrial Crops and Products, 97: 664-671.

Balooch, M., Sabahi, H., Aminian, H., Hossein, M., 2018. Intercalation technique can turn pomegranate industrial waste into a valuable by-product. LWT-Food Science and Technology, 98: 99-105.

Barbieri, R. L., Vizzotto, M., 2012. Pequenas frutas ou frutas vermelhas. Informe Agropecuário, Belo Horizonte, 33(268): 7-10.

Bermudez-Vasquez, M. J., Granados-Chinchila, F., Molina, A., 2019. Chemical composition and antimicrobial activity of the essential oil of Psidium guajava and Cymbopogon citratus. Agronomia Mesoamericana, 30(1): 147-163.

Bischoff, T. Z., Pintro, T. C., Paloschi, C. L., Coelho, S. R. M., Grzegozewski, D. M., 2013. Conservação pós-colheita da amora-preta refrigerada com biofilme e embalagem plástica. Revista Energia na Agricultura, 28(2): 109-114.

Cazón, P., Velazquez, G., Ramírez, J. A., Vázquez, M., 2017. Polysaccharide-based films and coatings for food packaging: A review. Food Hydrocolloids, 68: 136-148. 
Carnelossi, P.R., 2009. Óleos essenciais no controle pós-colheita de Colletotrichum gloeosporioides em mamão. Revista Brasileira de Plantas Medicinais, Botucatu, 11(4): 399-406.

Cia, P., Bron, I.U., Valentini, S.R.T., Pio, R., Chagas, E.A., 2007. Atmosfera modificada e refrigeração para a conservação pós-colheita de amora-preta. Bioscience Journal, 23(3): 11-16.

Curi, P.N., Pio, R., Moura, P.H.A., Tadeu, M.H., Nogueira, P.V., Pasqual, M., 2014. Produção de amora-preta e amora-vermelha em Lavras - MG. Ciência Rural, 45(8): 13681374.

Deng, Y., Wu., Li, Y., 2005. Changes in firmness, cell wall composition and cell wall hydrolases of grapes stored in high oxygen atmospheres. Food Researech International, 38: 769-776.

Dhital, R., Mora, N.B., Watson, D.G., Kohli, P., Choudhary, R., 2018. Efficacy of limonene nano coatings on post-harvest shelf life of strawberries. LWT-Food Science and Technology, 97: 124-134.

Ditzel, F.I., Prestes, E., Carvalho, B.M., Demiate, I.M., Pinheiro, L.A., 2017. Nanocrystalline cellulose extracted from pine wood and corncob. Carbohydrate Polymers, 157: 1577-1587.

Galus, S., Kadzinska, J., 2015. Food applications of emulsion-based edible films and coatings. Trends in Food Science and Technology, 45: 273-283.

Gol, N.B., Vyas, P.B., Rao, T.V.R., 2015. Evaluation of polysaccharide-based edible coatings for their ability to preserve the postharvest quality of Indian blackberry (Syzygium cumini L.). International Journal of Fruit Science, 15(2): 198-222. 
Hirsch, G.E., Facco, E.M., Rodriguesm, D.B., Vizzotto, M., Emanuelli, T., 2012. Caracterização físico-química de variedades de amora-preta da região sul do Brasil. Ciência Rural, 42(5): 942-947.

Jacques, A.C., Zambiazi, R.C., 2011. Fitoquímicos em amora-preta (Rubus spp.). Semina: Ciências Agrárias, Londrina, 32(1): 245-260.

Joo, M., Lewandowski, N., Auras, R., Harte, J., Almenar, E., 2011. Comparative shelf life study of blackberry fruit in bio-based and petroleum-based containers under retail storage conditions. Food Chemistry, 126: 1734-1740.

Kafkas, E., Kosar, M., Turemis, N., Baser, K.H.C., 2006. Analysis of sugars, organic acids and vitamin $\mathrm{C}$ contends of blackberry genotypes from Turkey. Food Chemistry, 97(4): 732-736.

Kim, J.H., Shim, B.S., Kim, H.S., Lee, Y.J., Min, S.K., Jang, D., Abas, Z., Kim, J., 2015. Review of nanocellulose for sustainable future materials. International Journal of Precision Engineering and Manufacturing-Green Technology, 2(2): 197-213.

Lavoine, N., Desloges, I., Dufresne, A., Bras, J., 2012. Microfibrillated celulose - Its barrier properties and applications in cellulosic materials: A review. Carbohydrate polymers, 90(2): 735-764.

Lawrence, B., Melgar, J. C., 2018. Harvest, handling, and storage recommendations for improving postharvest quality of blackberry cultivars. Horttechnology, 28(5): 578-583.

Lorenzetti, E.R., Monteiro, F.P., Souza, P.E., Souza, R.J., Scalice, H.K., Diogo, J.R., Pires, M.S. O., 2011. Bioatividade de óleos essenciais no controle de Botrytis cinerea isolado de morangueiro. Revista Brasileira de Plantas Medicinais, 13: 619-627.

Maisanaba, S., Llana-Ruiz-Cabello, M., Praena, D. G., Pichardo, S., Porto, M., Prieto, A., 2016. New advances in active packaging incorporated with essential oils or their main components for food preservation. Food Reviews International, 33(5): 447-515. 
Minolta. 1994. Precise Color Communication: Color Control from Feeling to Instrumentation. Osaka: Minolta Co. Ltda.

Santos Neto, J., Schwan-Estrada, K.R.F., Sena, J.O.A., Jardinetti, V.D., Alencar, M.D.R., 2016. Qualidade de frutos de tomateiro cultivado em sistema de produção orgânico e tratados com subprodutos de capim limão. Revista Ciência Agronômica, 47(4): 633-642.

Nsor-Antidana, J., Chen, M., Goff, H.D., Zhong, F., Sharif, H. R., Li, Y., 2017. Functionality and nutricional aspects of microcrystalline cellulose in food. Carbohydrate Polymers, 172: 159-174.

Oliveira, D.M., Rosa, C.I.L.F., Kwiatkowski, A., Clemente, E., 2013. Biodegradable coatings on the postharvest of blackberry stored under refrigeration. Ciência Agronômica, 44(2): 302-309.

Pereira, A.D., Cardoso, M.D., Abreu, L.R., Morais, A.R., Guimares, L.G.D., Salgado, A.P.S.P., 2008. Chemical characterization and inhibitory effect of essential oils on the growth of Staphylococcus aureus and Escherichia coli. Ciência e Agrotecnologia, 32(3): 887-893.

Rhim, J.W., Park, H.M., Ha, C.S., 2013. Bio-nanocomposites for food packaging applications. Progress in Polymer Science, 38: 1629-1652.

Rozwalka, L.C., Lima, M.L.R.Z.D., Mio, L.L.M., Nakashima, T., 2008. Extracts, decoctions and essential oils of medicinal and aromatic plants in the inhibition of Colleototrichum gloeosporioides and Glomerella cingulate isolates from guava fruits. Ciência Rural, 38(2): 301-307.

RStudio. 2018. Undelete and data recovery software. Software livre de ambiente de desenvolvimento integrado para $\mathrm{R}$ para análises estatísticas. $\mathrm{R}$ version 3.4.1. https://www.rstudio.com/ (accessed 11 March 2019). 
Sena, E.O.A., Couto, H.G.A.C., Paixão, A.R.C., Silveira, M.P.C., Oliveira Junior, L.F.G., Carnelossi, M.A.G., 2016. Utilização de biofilme comestível na conservação pós-colheita de pimentão verde (Capsicum annuum L.). Scientia Plena, 12(8): 1-9.

Sethu, K. M. P., Prabha, T. N., Tharanathan, R. N., 1996. Post-harvest bicochemical changes associated with the softening phenomenon in Capsicum annuиm fruits. Phytochemistry, 42: 961-966.

Soethe, C., Steffens, C.A., Amarante, C.V.T., Martin, M.S., Bortolini, A.J., 2016. Qualidade, compostos fenólicos e atividade antioxidante de amoras-pretas 'Tupy' e 'Guarani' armazenadas a diferentes temperaturas. Pesquisa Agropecuária Brasileira, Brasília, 51(8): 950-957.

Taiz, L., Zeiger, E., 2013. Fisiologia Vegetal. 5ª edição, Porto Alegre: Artmed Editora.

Tosun, I., Ustum, N. S., Tekguler, B., 2008. Physical and chemical changes during ripening of blackberry fruits. Scientia Agricola, 65(1): 87-90.

Trigo, J. M., Albertini, S., Spoto, M.H.F., Sarmento, S.B.S., Lai Reyes, A.E., Sarriés, G.A., 2012. Efeito de revestimentos comestíveis na conservação de mamões minimamente processados. Brazilian Journal of Food Technology, 15(2): 125-133.

Turmanidze, T.V., Gulua, L.K., Jgenti, M., Wicker, L., 2016. Effect of Calcium Chloride Treatments on Quality Characteristics of Blackberry Fruit During Storage. International Journal of Food and Allied Sciences, 2(2): 36-41.

Yamamoto, E.L.M., Ferreira, R.M.A., Fernandes, P.L.O., Albuquerque, L.B., Alves, E.O., 2011. Função do cálcio na degradação da parede celular vegetal. Revista Verde de Agroecologia e Desenvolvimento Sustentável, 6: 49-55. 
Table 1. Average pH data, titratable acidity (TA), soluble solids (SS) and fresh weight loss (FWL) of blackberry cv. Brazos treated with microfibrillated nanocellulose coating associated with lemongrass essential oil, in function of the evaluation period. Where: (NC) nanocellulose and (EO) essential oil.

\begin{tabular}{|c|c|c|c|c|c|c|}
\hline \multirow{3}{*}{$\begin{array}{c}\text { Evaluation after } \\
\text { storage } \\
\text { (days) }\end{array}$} & \multicolumn{6}{|c|}{ Fruit treatment at postharvest } \\
\hline & Control & $\begin{array}{c}\mathrm{EO}+\mathrm{NC} \\
0 \%\end{array}$ & $\begin{array}{c}\text { EO+NC } \\
0.2 \%\end{array}$ & $\begin{array}{c}\mathrm{EO}+\mathrm{NC} \\
0.4 \%\end{array}$ & $\begin{array}{c}\mathrm{EO}+\mathrm{NC} \\
0.6 \%\end{array}$ & $\begin{array}{c}\mathrm{EO}+\mathrm{NC} \\
0.8 \%\end{array}$ \\
\hline & \multicolumn{6}{|c|}{$\mathrm{pH}$} \\
\hline 0 & $3.05 \mathrm{~b}$ & $3.02 \mathrm{c}$ & $2.97 \mathrm{~b}$ & $3.06 \mathrm{c}$ & $3.08 \mathrm{c}$ & $2.95 \mathrm{~b}$ \\
\hline 3 & $3.37 \mathrm{a}$ & $3.22 \mathrm{~b}$ & $3.38 \mathrm{a}$ & $3.52 \mathrm{~b}$ & $3.36 \mathrm{~b}$ & $3.45 \mathrm{a}$ \\
\hline 6 & - & $3.52 \mathrm{a}$ & $3.37 \mathrm{a}$ & $3.66 \mathrm{a}$ & $3.56 \mathrm{a}$ & $3.47 \mathrm{a}$ \\
\hline \multirow[t]{2}{*}{$\mathrm{CV}(\%)$} & \multicolumn{6}{|c|}{2.05} \\
\hline & \multicolumn{6}{|c|}{ Titratable acidity (\% malic acid) } \\
\hline 0 & $3.07 \mathrm{a}$ & $1.54 \mathrm{a}$ & $2.18 \mathrm{a}$ & $2.30 \mathrm{a}$ & $2.05 \mathrm{a}$ & $1.80 \mathrm{a}$ \\
\hline 3 & $1.18 \mathrm{~b}$ & $1.28 \mathrm{~b}$ & $1.28 \mathrm{~b}$ & $1.28 \mathrm{~b}$ & $1.28 \mathrm{~b}$ & $1.28 \mathrm{a}$ \\
\hline 6 & - & $1.28 \mathrm{~b}$ & $1.28 \mathrm{~b}$ & $1.28 \mathrm{~b}$ & $1.28 \mathrm{~b}$ & $1.28 \mathrm{a}$ \\
\hline $\mathrm{CV}(\%)$ & \multicolumn{6}{|c|}{24.62} \\
\hline & \multicolumn{6}{|c|}{ Soluble solids ( ${ }^{\circ}$ Brix) } \\
\hline 0 & $7.3 \mathrm{a}$ & $6.4 \mathrm{~b}$ & $6.5 \mathrm{ab}$ & $6.2 \mathrm{a}$ & $7.0 \mathrm{~b}$ & $5.9 \mathrm{~b}$ \\
\hline 3 & $7.2 \mathrm{a}$ & $8.2 \mathrm{a}$ & $5.9 \mathrm{~b}$ & $7.5 \mathrm{a}$ & $8.8 \mathrm{a}$ & $8.2 \mathrm{a}$ \\
\hline 6 & - & $6.0 \mathrm{~b}$ & $7.8 \mathrm{a}$ & $7.4 \mathrm{a}$ & $6.8 \mathrm{~b}$ & $6.0 \mathrm{~b}$ \\
\hline $\mathrm{CV}(\%)$ & \multicolumn{6}{|c|}{14.47} \\
\hline & \multicolumn{6}{|c|}{ Fresh weight loss (g) } \\
\hline 0 & $5.15 \mathrm{a}$ & $5.27 \mathrm{a}$ & $5.27 \mathrm{a}$ & $5.50 \mathrm{a}$ & $4.97 \mathrm{a}$ & $5.76 \mathrm{a}$ \\
\hline 3 & $4.63 \mathrm{a}$ & $4.73 \mathrm{~b}$ & $4.85 \mathrm{~b}$ & $4.91 \mathrm{~b}$ & $4.50 \mathrm{~b}$ & $5.24 \mathrm{~b}$ \\
\hline 6 & - & $4.10 \mathrm{c}$ & $4.16 \mathrm{c}$ & $4.27 \mathrm{c}$ & $3.94 \mathrm{c}$ & $4.50 \mathrm{c}$ \\
\hline $\mathrm{CV}(\%)$ & \multicolumn{6}{|c|}{5.68} \\
\hline
\end{tabular}

Averages followed by the same lowercase letter in the column do not differ from each other by the Student Newman Keuls at $\mathrm{p} \leq 0.05$. The treatments with "-" means that the evaluations were not performed because of the complete deterioration of the fruit. 

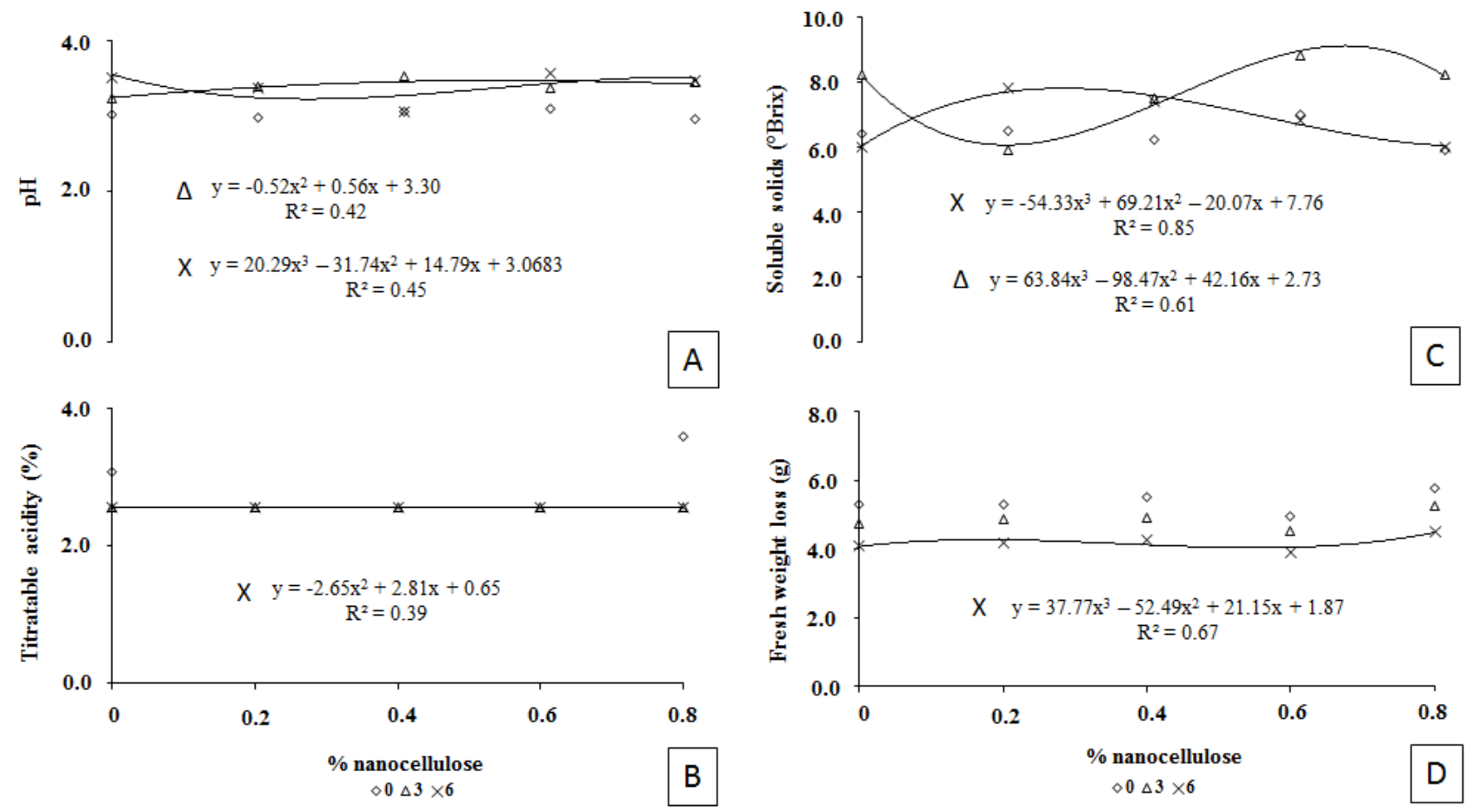

Figure 1. $\mathrm{pH}(\mathrm{A})$ : $\mathrm{pH}$, titratable acidity (B), soluble solids (C) and fresh weight loss (D) of blackberry cv. Brazos, in function of the different nanocellulose associated with lemongrass essential oil concentrations. 
Table 2. Average luminosity data $\left({ }^{*} \mathrm{~L}\right)$, Hue angle (hue) and chroma (Chroma) of blackberries cv. Brazos treated with microfibrillated nanocellulose coating associated with lemongrass essential oil, in function of the evaluation period. Where: (NC) nanocellulose and (EO) essential oil.

\begin{tabular}{|c|c|c|c|c|c|c|}
\hline \multirow{3}{*}{$\begin{array}{c}\text { Evaluation } \\
\text { after } \\
\text { storage } \\
\text { (days) }\end{array}$} & \multicolumn{6}{|c|}{ Fruit treatment at postharvest } \\
\hline & Controle & $\begin{array}{c}\mathrm{EO}+\mathrm{NC} \\
0 \%\end{array}$ & $\begin{array}{c}\mathrm{EO}+\mathrm{NC} \\
0.2 \%\end{array}$ & $\begin{array}{c}\mathrm{EO}+\mathrm{NC} \\
0.4 \%\end{array}$ & $\begin{array}{c}\mathrm{EO}+\mathrm{NC} \\
0.6 \%\end{array}$ & $\begin{array}{c}\mathrm{EO}+\mathrm{NC} \\
0.8 \%\end{array}$ \\
\hline & \multicolumn{6}{|c|}{ Luminosity $(* \mathrm{~L})$} \\
\hline 0 & $15.38 \mathrm{a}$ & $19.14 \mathrm{a}$ & $18.58 \mathrm{ab}$ & $18.11 \mathrm{a}$ & $16.94 \mathrm{~b}$ & $16.68 \mathrm{a}$ \\
\hline 3 & $14.75 \mathrm{a}$ & $19.55 \mathrm{a}$ & $17.20 \mathrm{~b}$ & $15.62 \mathrm{~b}$ & $17.66 \mathrm{ab}$ & $16.10 \mathrm{a}$ \\
\hline 6 & - & $18.26 \mathrm{a}$ & $20.32 \mathrm{a}$ & $19.82 \mathrm{a}$ & $19.69 \mathrm{a}$ & $15.85 \mathrm{a}$ \\
\hline \multirow{2}{*}{$\mathrm{CV}(\%)$} & \multicolumn{6}{|c|}{9.60} \\
\hline & \multicolumn{6}{|c|}{ Hue Angle } \\
\hline 0 & $26.80 \mathrm{a}$ & $17.86 \mathrm{a}$ & $17.74 \mathrm{a}$ & $17.98 \mathrm{~b}$ & $20.52 \mathrm{a}$ & $18.98 \mathrm{a}$ \\
\hline 3 & $29.86 \mathrm{a}$ & $16.83 \mathrm{a}$ & $15.95 \mathrm{a}$ & $29.00 \mathrm{a}$ & $14.11 \mathrm{a}$ & $22.04 \mathrm{a}$ \\
\hline 6 & - & $17.07 \mathrm{a}$ & $15.96 \mathrm{a}$ & $16.43 \mathrm{~b}$ & $22.21 \mathrm{a}$ & $29.30 \mathrm{a}$ \\
\hline $\mathrm{CV}(\%)$ & \multicolumn{6}{|c|}{35.04} \\
\hline & \multicolumn{6}{|c|}{ Chroma } \\
\hline 0 & $1.10 \mathrm{a}$ & $9.12 \mathrm{a}$ & $10.20 \mathrm{~b}$ & $18.11 \mathrm{a}$ & $16.94 \mathrm{~b}$ & $16.68 \mathrm{a}$ \\
\hline 3 & $1.78 \mathrm{a}$ & $10.52 \mathrm{a}$ & $9.67 \mathrm{~b}$ & $15.62 \mathrm{~b}$ & $17.66 \mathrm{ab}$ & $16.10 \mathrm{a}$ \\
\hline 6 & - & $8.15 \mathrm{a}$ & $13.73 \mathrm{a}$ & $19.82 \mathrm{a}$ & $19.69 \mathrm{a}$ & $15.84 \mathrm{a}$ \\
\hline $\mathrm{CV}(\%)$ & \multicolumn{6}{|c|}{25.29} \\
\hline
\end{tabular}

Averages followed by the same lowercase letter in the column do not differ from each other by the Student Newman Keuls at $\mathrm{p} \leq 0.05$. The treatments with "-" means that the evaluations were not performed because of the complete deterioration of the fruit. 

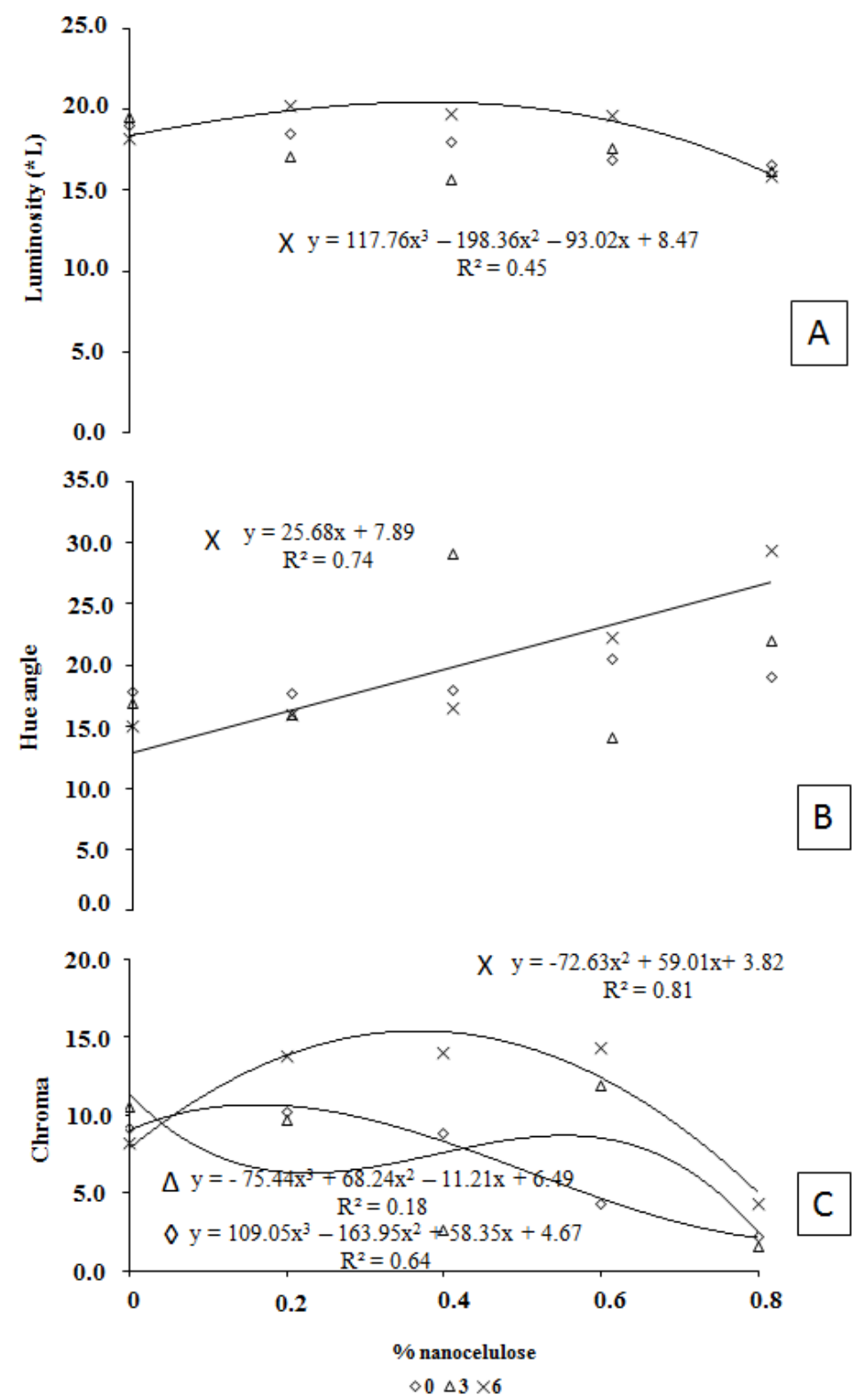

Figure 2. Luminosity (*L) (A), Hue angle (B) and Chroma (C) of blackberry cv. Brazos, in function of different nanocellulose associated with lemongrass essential oil concentrations. 